\title{
Retraction: Value of cardiac magnetic resonance imaging in systemic sclerosis
}

\author{
Narumol Chaosuwannakit ${ }^{1}$, Pattarapong Makarawate ${ }^{2}$ \\ ${ }^{1}$ Radiology Department, Faculty of Medicine, Khon Kaen University, Thailand \\ ${ }^{2}$ Internal Medicine Department, Faculty of Medicine, Khon Kaen University,Thailand
}

Reumatologia 2018; 56, 2: 92-98

DOI: https://doi.org/10.5114/reum.2018.75520

Online publish date: 2018 May 9

This article has been retracted following a review by the Editorial Board. It has come to light that there is a significant overlap between the article and one that had already been published:

Hachulla AL, Launay D, Gaxotte V, de Groote P, Lamblin N, Devos P, Hatron PY, Beregi JP, Hachulla E. Cardiac magnetic resonance imaging in systemic sclerosis: a cross-sectional observational study of 52 patients. Ann Rheum Dis 2008; 68(12): 1878-1884. doi: 10.1136/ard.2008.095836. Epub 2008 Dec 3. 